\title{
147. Lake Akanuma, a Siderotrophic Lake, at the Foot of Volcano Bandai, Hukusima Prefecture, Japan.
}

\author{
By Shinkichi Yoshimura. \\ Geographical Institute, College of Literature and Science, Tokyo. \\ (Comm. by H. YABE, M.I.A., Dec. 12, 1935.)
}

Mt. Bandai $(1,819 \mathrm{~m})$ is a volcano in northeastern Honsy û and famous for its sudden violent explosion which occurred on July 15, 1888, when two-thirds of its peak, Mt. Kobandai, blew off. A mud-flow of the material that formed Kobandai, rushed down the valley of the river Nagase and dammed it, resulting in making there four lakes, Hibarako (10.27 sqkm, $31 \mathrm{~m}$. deep), (Onogawako (1.41 sqkm. $21.8 \mathrm{~m}$ ), Sobarako $(0.37 \mathrm{sqkm}, 12.0 \mathrm{~m})$, and Akimotoko $(3.87 \mathrm{sqkm}, 34.5 \mathrm{~m})$. There are still remains today, as remnants, many small undrained depressions on the surface of the mud-flow, one hundred or more in total number; they are called Gosikinuma, or five-coloured lakes, because of their water being tinged with emerald, bright blue, red or green.

Akanuma, in one of these depressions, is a small narrow lake $(2,300 \mathrm{sqkm})$ at a height of $795 \mathrm{~m}$, without any outflow and surrounded on all sides by low cliffs of the old mud-flow now overgrown with pine trees. The writer visited this lake with Messrs K. Negoro and A. Yamamoto in August, 1935. Upon sounding at 8 points from a rubber boat, its maximum depth was measured to be $4.0 \mathrm{~m}$; the bottom was as a whole flat.

The most striking feature of the lake was the extraordinary reddish green colour of its water, Akanuma in Japanese meaning red lake or pond. The water was turbid owing to ferric oxide in suspension; the white disc is invisible at $1.2 \mathrm{~m}$.

The following hydrographical observations were made in the afternoon of 18th, under the cloudless sky (Table I).

TABLE I.

\begin{tabular}{l|c|ccc|c|c|c|c}
\hline $\begin{array}{c}\text { Depth } \\
\mathrm{m}\end{array}$ & $\begin{array}{c}\text { Temp. } \\
{ }^{\circ} \mathrm{C}\end{array}$ & $\mathrm{pH}$ & $\begin{array}{c}\mathrm{O}_{2} \\
\mathrm{c.c} / 1\end{array}$ & $\begin{array}{c}\mathrm{O}_{2} \\
\%\end{array}$ & $\begin{array}{c}\mathrm{K}_{18} \\
1 \times 10^{-4} \\
\mathrm{ohm}^{-1}\end{array}$ & $\begin{array}{c}\mathrm{Mn} \\
\mathrm{mg} / 1\end{array}$ & $\begin{array}{c}\mathrm{Fe} \\
\mathrm{mg} / 1\end{array}$ & $\begin{array}{c}\mathrm{Cl} \\
\mathrm{mg} / \mathbf{1}\end{array}$ \\
\hline 0 & 21.0 & 3.3 & 2.70 & 47 & 15.2 & 9.7 & 12.8 & 82 \\
0.5 & 16.58 & 3.5 & 0.48 & 8 & - & - & - & - \\
1 & 14.51 & 3.6 & 0.00 & 0 & 14.9 & 7.6 & - & 79 \\
2 & 13.16 & 3.6 & 0.00 & 0 & - & - & - & - \\
3 & 12.89 & 3.6 & 0.00 & 0 & 15.5 & 8.5 & 15.0 & 96 \\
3.7 & 13.05 & & & & & & & \\
& (mud) & & & & & & & \\
\hline
\end{tabular}


The temperature dropped abruptly soon beneath the surface; the water showed strong acidic reaction and the acidity diminished toward the bottom.

The quantity of dissolved oxygen at the surface was a little less than half the amount required for saturation, and that at $1 \mathrm{~m}$ only $8 \%$ of it, while below $1 \mathrm{~m}$ oxygen completely disappeared. This stratification of oxygen is similar to that in high moor ponds, but is due to the reduction by ferrous iron and manganous manganese dissolved to a considerable amount in the water, instead of being due to that of excess humus colloid in the latter case. Owing to the presence of a large quantity of calcium sulphate $\left(\mathrm{Ca}{ }^{*}=202 ; \mathrm{SO}_{4}^{\prime \prime}=461 \mathrm{mg} / 1\right)$, the water showed extraordinary high electric conductivity. The water sample collected on July 17,1931 , had the total residue of $1,454 \mathrm{mg} / 1$.

Besides much iron, the water contained an enormous amount of manganese, not surpassed by any non-idiothermal lake, hitherto recorded of the world. The rocks of the Volcano Bandai are noted for their high percentage of manganese, and in consequence all the lake-water of the Gosikinuma Group contain large amounts of manganese (1-6 mg/1) though less than in Akanuma. In the amount of iron it is surpassed only by the crater lake Okama of the Volcano Zaô, Miyagi prefecture; the water-sample collected by Mr. Y. Konno in the same season (Aug. $18,1935)$ from the latter was strongly acidic $(\mathrm{pH}=2.5)$ and contained iron of $19.2 \mathrm{mg} / 1$, or about $50 \%$ more than that of Akanuma.

Large quantities of iron and manganese are brought into the lake by the acidic underground water flowing under the mud-flow which has their compounds derived in solution from the rocks in contact with sulphuric acid. Entering the lake, the water is aerated, warmed and its acidity diluted by precipitation, resulting in the supersaturation of iron and the consequent crystallization of minute crystals of ferric oxide, which are soon coagulated under the high concentration of salts and precipitate to the bottom. The turbidity of the water is probably due to temporal suspension of iron oxide, thus produced; upon keeping the lake water for one or two days in a glass bottle, particles of ferric oxide partly settle to the bottom.

The biocoenose of the lake is peculiar and generally poor in production. The shore is surrounded by a narrow belt of Phragmites communis, whose roots were thickly coated with ferric oxide. The Phragmites zone was in turn fringed by a narrow zone of Leptodictyum sp., which usually covers the bottom of the inorganic acidotrophic lakes ${ }^{1}$ as Osoresanko in Aomori Prefecture $(\mathrm{pH}=3.1)$ and many lakes of the Gosikinuma group ( $\mathrm{pH}=4.3-4.7)$. This musei was incrusted with ferric oxide, growing as long filaments of iron bacteria. No planktonic or benthonic organisms, except a few iron bacteria, were found.

The paucity of aquatic life and its restriction to only a small number of species, support the claim that the lake should be distinguished as the siderotrophic lake type than the acidotrophic, as, in addition to

1) Yoshimura, S.: Arch. f. Hydrob. 26 (1933), 197-202. 
the acidity, high iron content of the water plays a great role on the disharmonic character of the lake, in strong contrast to the lake Osoresanko' $(\mathrm{pH}=3.1, \mathrm{Fe} .0 .4 \mathrm{mg} / 1)$, which though more acidic, but being poorer in iron, contains a very large number of species.

1) Yoshimura, S.: Proc. 10 (1934), 475-478. 